\title{
Managing Tourism Cultural : Enhance The Local Value And Increasing Experience Of Travelers
}

\author{
Dedy Wijayanto ${ }^{1}$, Dian Octarina ${ }^{2}$ \\ ${ }^{1,2}$ Sekolah Tinggi Pariwisata Trisakti, Jakarta, Indonesia \\ deddywijayanto@stptrisakti.ac.id, dianoctarina@stptrisakti.ac.id
}

\begin{abstract}
Cultural tourism is a tourist visiting the cultural heritage of the past tens or even hundreds of ago. Cultural tourism needs to be taken seriously and carefully so as to provide benefits to others. Various kinds that are included into cultural tourism, among others; temples, dances, historic buildings and so on.

This study aims to address the cultural heritage of the past to provide added value for tourists who come to visit, especially young people as a form of learning. And also not forget the past and the life of the ancestors.The method used in the study using ethnographic study approach, observation and see the phenomena that exist.
\end{abstract}

Key words : cultural tourism, local values, tourists .

\section{INTRODUCTION}

In Indonesia there are various kinds of past relics that need attention from all stakeholders, among others; the community itself, the government, the other party's fiber that is considered to represent it. Cultural tourism can consist of anything in between; temple buildings, old mosques, churches, temples, old ships that are no longer functional, palace or palace, Baliem valley festivaal, Kerakataau festival, Tana Toraja, museum items and many others.Many relics of the past that are less well handled less or less in interest. the community has no awareness of how to care for and preserve past cultures.

Some of the problems that arise are the lack of funds to treat to become neglected, the lack of personnel who understand how to deal with historic objects. Managing Quality Cultural Tourism is an authoritative look at how to manage cultural tourist sites to best meet the needs of the visitors, the presenters and the site itself. As cultural tourism increases the management of heritage sites becomes more complex. Priscilla Boniface addresses these crucial management issues using a marketing approach to identify the needs of all concerned.

Tourism industry is first, a service industry. Accordingly, tourism establishments are very labor intensive and they serve millions of people throughout the world. Thus they need to pursue and accord the developing changes to their own organization. Today, quality is of first priority for the tourism properties that matters. Hence adapting to change indicates many changes, especially cultural change within the organization.( Gocke Ozdemir ( 2007)

Cultural heritage assets as ensuring a higher level of quality of life for the local community and have broadened the heritage significance assessment criteria to include assets of social value to that community. (Hillary Du Cros, 2009).

Establishing sustainable cultural tourism through greater stakeholder involvement in the planning, marketing and management of heritage assets might sound simple. However, the reality is that stakeholders are not always easy to deal with, whether you are a government official, a consultant or a community leader facilitating a project. Hall and McArthur observe that for many such facilitators and project leaders, one of the greatest difficulties in dealing with stakeholders is coping with the range of values and interests that occur in relation to heritage

Cultural tourism can be defined as, "A form of tourism that relies on a destination's cultural heritage assets and transforms them into products that can be consumed by tourists" (McKercher and du Cros 2002: 6). What is understood as modern cultural tourism has only been studied in detail from the 1980s onwards (Tighe 1986; Boniface and Fowler 1993).

Pendit, (1990) mentions cultural tourism is a journey undertaken on the basis of a desire to broaden one's view of life by making visits to other places or abroad, studying the state of the people, their 
customs and customs, their way of life, their culture and art . Today, cultural tourism is growing rapidly because of a new trend among tourists that is the tendency to seek something unique and authentic from a culture.

\section{METHODS}

The research method used is ethnography study approach, observation and arrange the phenomena that occur around it. This method cites the model of interviews conducted against residents or who represent them from various professions and occupations and positions.

Qualitative research is research on descriptive research and tend to use analysis. Process and meaning (subject perspective) are more highlighted in qualitative research. Theoretical basis is used as a guide to focus the research in accordance with the facts in the field. In addition the theoretical basis is also useful to provide an overview of the background research and as a material discussion of research results.

There is a fundamental difference between the role of theoretical foundation in quantitative research with qualitative research. In quantitative research, research departs from theory to data, and ends in acceptance or rejection of the theory used; whereas in qualitative research the researcher departs from the data, utilizing the existing theory as the explanatory material, and ending with a "theory".

Qualitative research is much more subjective than quantitative research or surveys and using methods is very different from gathering information, especially individuals, in using in-depth interviews and focus groups. The nature of this type of research is that open research and exploration ends in relatively small numbers of interviewed people in depth.

\section{RESULT AND DISCUSSION}

\section{Location and Time of Study}

Cangkuang temple is a Hindu temple located in Kampung Pulo, Cangkuang area, District of Leles, Garut, West Java. This temple is also the first time found in Tatar Sunda and is the only Hindu temple in Tatar Sunda. This temple is located adjacent to the grave of Embah Dalem Arief Muhammad, an ancient tomb of an Islamic religious leader believed to be the ancestor of the inhabitants of Cangkuang Village.

Cangkuang Village is surrounded by four large mountains in West Java, which include Mount Haruman, Mount Kaledong, Mount Mandalawangi and Mount Guntur. The name of Cangkuang Temple is taken from the name of the village where the temple is located. The word 'Cangkuang' itself is the name of a kind of plant pandanus ( pandanus furcatus), which is widely found around the grave, Embah Dalem Arief Muhammad, ancestor of Kampung Pulo. Cangkuang leaves can be utilized to make a hood, mat or wrapping. Cangkuang cultural reserve is located on a mainland in the middle of a small lake (in Sundanese language called it), so to reach the place through the main route, visitors must cross by using a raft. Originally Kampung Pulo was surrounded entirely by lakes, but now only the northern part is still a lake, the southern part has turned into rice fields. In addition to the temple, on the island there are also traditional Kampung Pulo settlements, which also become part of the cultural heritage area.

Cangkuang temple is located on a small island whose shape extends from west to east with an area of 16.5 ha. This small island is located in the middle of Lake Cangkuang at coordinates $106^{\circ} 54^{\prime} 36.79$ "East Longitude and $7^{\circ} 06^{\prime} 09^{\prime \prime}$ South Latitude. In addition to the island that has a temple, in this lake there are also two other islands with a smaller size.

The location of this Cangkuang lake topografi found in a fertile valley approximately 600-m l.b.1. which is surrounded by mountains: Mount Haruman $(1,218 \mathrm{~m} \mathrm{lbl})$ to the east - north, Pasir Kadaleman $(681 \mathrm{mlbl})$ in the south east, Pasad Gadung $(1841 \mathrm{~m} \mathrm{lbl})$ to the south, Mount Guntur $(2,849 \mathrm{~m} \mathrm{lbl})$ to the west- south, Gunung Malang $(1,329 \mathrm{~m} \mathrm{lbl})$ to the west, Mount Mandalawangi in the north-north, and Mount Kaledong $(1,249 \mathrm{~m} \mathrm{lbl})$ to the north.

The study took place from 1 to 7 January 2018 


\section{CONCLUSION}

\section{Description of the research object}

Cangkuang temple is located on the edge of an artificial lake that surrounds the hill of the temple. To reach the visitors must use a bamboo raft to cross with a roughly Rp. 100,000, - to go home in a blaze. To enter the temple area must pay Rp 5.000.0 per person

Cangkuang temple measuring $4 \times 4 \mathrm{~m} 2$ and beside there is the tomb of Ki Arief, as the spreader of Islam at the beginning of his arrival. There is also a museum that deals pictures of the construction of temples. Because this temple had collapsed and for two years successfully rearranged.

There is no manuscript or writing that says the year how this relics because only according to the estimate that is in the 8th century. Cangkuang is the name of a cempedak tree that grows around this place but not eatable. So called this temple with cangkung temple to make it easier to remember it.

\section{Result .}

As a relic of the past then, this temple still deserves attention from the government and surrounding communities. The local government gives full attention to this hindu relic and is well maintained.

From the interview with the museum guard who is located near the temple site, it is said that the community thought that this site brings blessings to the people around him and so there are many tourists who want to visit and come to this place. There is no relic of the manuscript from the past that could explain the existence of this site.

Actually the site of this temple had collapsed and was found by an archaeologist from western Java and then try to be reassembled although not all the former temple is still intact. Some are gone or destroyed by natural disasters. Thanks to the persistence of such archaeologists and with the help of the community can be rearranged. But the statue of syiwa which is inside the temple is still original as well as its stupas.

There are ten custom homes that are hundreds of years old from old age and need improvement and still occupied by his grandchildren as the successor. Unfortunately the descendants are not willing if the house is used as a homestay for tourists. Many food vendors or souvenirs who peddle their merchandise around the temple area that will disturb the comfort of visitors.

\section{Suggestion}

It needs coaching from the stakeholders, especially the Government to awaken the community to make their custom house repaired and made as a temporary residence or homestay. The museum building is very sad and need care so that tourists want to visit and see this historical relics.

\section{REFERENCES}

Boniface, Priscilla and Peter Fowler (1993), Heritage and Tourism in 'the Global Village', London: Routledge

Gokce Ozdemir.2007. "Cultural Change Management And Quality in The Tourism Industry Journal of Yasar University". Vol 2 no 5.

Dyah Safitri · "Pengembangan Potensi Desa Wisata Berbasis Budaya Tinjauan Terhadap Desa Wisata Di Jawa Tengah. Jurnal Vokasi Indonesia. Volume 4 No 1. Tahun 2016.

du Cros,Hillary. "Emerging Issues for Cultural Tourism in Macau”. Journal of Current Chinesse Affair. 2009 ISSN: 1868-4874,

du Cros, Hilary (2007), Too Much of a Good Thing? Visitor Congestion Management Issues for

Popular World Heritage Tourist Attractions, in: Journal of Heritage Tourism, 2, $3, \quad 225-$ 238.

du Cros, Hilary (2006), Managing visitor impacts in Lijiang, China, in: Anna Leask and Alan Fyall (eds.), Managing World Heritage Sites, London: Butterworth- Heinemann, 205214.

du Cros, Hilary and Yok-shui Lee (2007), Cultural Heritage Management in China:

Preserving the Pearl River Delta Cities, London: Routledge.

du Cros, Hilary and Frances Kong (2006), A Preliminary Study of Factors Influencing 
Congestion at Popular World Heritage Tourist Attractions in Macao, unpublished report to the Office of the Secretary of Social and Cultural Affairs, Macau SAR Government.

Tighe, Anthony (1986), The Arts/ Tourism Partnership, in: Journal of Travel

Research, 24, 3, 2-5.

"Candi Cangkuang". Perpustakaan Nasional Republik Indonesoa. Diakses tanggal $25 \quad$ Februari 2013.

Muljana, Slamet (2005). Runtuhnya kerajaan Hindu-Jawa dan timbulnya negara-negara Islam di Nusantara. PT LKiS Pelangi Aksara. p. 74. ISBN 9798451163.ISBN 978-End

The gratitude is addressed to :

Mr. Jacki from conservation hall "Banten Cultural Heritage and as a guardian of museum and temple site.

1. Mr. Asep as an elder and still descendant of Kyai Arief (the spreader of Islam in this area).

2. And the people who are not mentioned one by one.

Hopefully the results of this study useful. 